\title{
Global South Perspectives on Stonewall after 50 Years, Part II- Brazilian Stonewalls: Radical Politics and Lesbian Activism
}

\author{
Flávia Belmont* \\ Amanda Álvares Ferreira**
}

\begin{abstract}
The riots against a New York City police raid at the Stonewall Inn bar in June, 1969, are often identified as having sparked the movement for LGBT rights, and the commemoration of the riots one year later in June, 1970, inaugurated a series of annual LGBT Pride events that continues to this day worldwide. In this two-part Forum, we reflect on the contradictory effects of Stonewall's international legacy. In this second part of the Forum, Ferreira and Belmont investigate the ways in which 'Stonewall' has been appropriated specifically in Brazil, both during the civil-military dictatorship and in the current fraught political moment. Belmont locates current mismatches between LGBT and queer struggles in Brazil by juxtaposing more mainstream visions of LGBT politics with the margins they create, especially the marginalization of travestis. Belmont exposes the way that dominant LGBT discourse and practices reinforce the continuous violence over dissident bodies and proposes that we look at travestis' experiences and arguments as necessary contributions to a more radical (queer) politics. In the final contribution, Ferreira recapitulates the political demands of NYC's Stonewall events and contrast them to the revolutionary claims of what was called a 'Brazilian Stonewall.' Considering the protagonism of lesbian movements in such events in Brazil, her contribution analyzes, from a queer perspective, the embrace of a multiplicity of identifications in contemporary lesbian activism. She argues that this move creates potentialities for responding to structural violences, while also speaking to questions such as the judicialization and commercialization of LGBTTI causes and homonormativity.
\end{abstract}

Keywords: Stonewall; lesbian activism; homonormativity; Brazilian queer politics; LGBT conservatism; travesti agency.

\footnotetext{
* Pontifical Catholic University of Rio de Janeiro (PUC-Rio), Rio de Janeiro-RJ, Brazil; flabelmont@gmail.com. ORCID iD 0000-0002-9378-6158.

** Pontifical Catholic University of Rio de Janeiro (PUC-Rio), Rio de Janeiro-RJ, Brazil; a.alvaresf@gmail.com. ORCID iD 0000-0002-5563-6001.
} 


\section{Stonewall from Another Angle: Setting a Radical Dialogue in Brazil}

Flávia Belmont

A milestone of gay power, the Stonewall uprisings are known as the most important episode of the LGBT movement worldwide, symbolising resistance to police repression and giving impetus to the organisations and struggles that took shape from the 1970s onwards. According to Simões and Facchini (2009), at the time of the Stonewall revolt which took place in New York in 28 June 1969 and went on for five days, the US underground scene was at its peak with the hippie, Black Power and counterculture movements. Back then, sexual freedom was a fundamental issue, since non-cis/heteronormative behaviour was criminalised.

Protests strengthened collective ideas and queer movements, resulting in the first Pride Parade in 1970, which served as an inspiration for its continuing history in the USA and the emergence of Pride Parades in several other countries. According to Robert Schneider Jr. (2019), the centrality of parades as a political instrument strengthened two particular premises: speaking out and coming out of the closet.

Since Stonewall, claims on identity and sex politics have been diverse among queer organisations in the US. Following Bronski (2019), Stonewall could be referred to as uprisings on behalf of the right to engage in homosexual acts, the right to have a sex life and behave differently from heterosexual norms. Nonetheless, Sears (2005) argues that reformist movements have always existed and confronted radical claims and are currently in the spotlight, having disproportionately set the terms of the debate to the general public in the USA. In the last decades, the goal of most movements has shifted to the right to fit non-cis/heterosexual identities into the mainstream, i.e., a politics of recognition based on fixed identities - which also happened in Brazil. Importantly, the HIV/AIDS epidemics played its part in inciting the demonisation of queer people, causing shame, suffering and reorienting a significant parcel of queer efforts toward institutional negotiations for diversity and recognition in bureaucratic terms, in spite of radical groups moved by anger, occupations and interventions such as ACT UP (Bronski 2019; Long 2005).

In Brazil, the first Pride events took place in the 1990s (Simões and Facchini 2009). In 2019 , some parades had as a motif the memory and celebration of the $50^{\text {th }}$ anniversary of Stonewall, including the two largest in the country: Rio de Janeiro and São Paulo. In the latter, organisers wrote a manifesto briefly asserting the importance of the Stonewall revolts and looking back onto remarkable events and achievements in Brazilian LGBT history. At the end, the text reinstates a commitment of the Parade organizers to 'respect, acceptance, tolerance and rights' (ParadaSP 2019).

Although tendencies to institutional assimilation and rights-based activism prevail both in Brazil and the USA, Brazilian activisms achieved a more or less organic relation with the State during the country's redemocratisation process, ${ }^{1}$ which resulted in public health initiatives regarding HIV/AIDS treatment and prevention in the 1980s. Furthermore, the main agenda in Brazil has been anti-homophobia rather than same-sex 
marriage (Miskolci 2011). And, contrarily to what happens in the USA, out and proud right-wing or conservative activists and public figures are still rising in Brazil and do not claim LGBT-oriented agendas. Therefore, Brazilian circumstances seem less fitting to parallels with concepts such as homonationalism (Puar 2007), homonormativity (Duggan 2003) and the image of gay gentrified neighbourhoods where rainbow families reside (Sears 2005).

Even so, as argues Miskolci (2011), Brazilian LGBT movements seem too concerned with identity and rights, haunted by a stigmatisation of queer ideas as if queering meant simply opposing any form of identity. I defend that queer thought has at its core the unscrambling of cis/heterosexuality as a deeply rooted cultural and institutional structure. As such, queer theory and praxis are potentially able to politicise identity in their social contexts, building complex narratives on politics departing from a problematisation of binary and gender-conforming systems, which is a necessary input for the prevailing debates in LGBT movements in Brazil today.

\section{Queer and identitarian (non)conversations}

The dichotomy between queer activism/academia and identitarian social movements is very much alive, especially because queer thought has emerged in Brazil via academic theorists. Guacira Lopes Louro, Richard Miskolci, Leandro Colling, Berenice Bento, Pedro Paulo Gomes Pereira and Larissa Pelúcio are some of the most acclaimed Brazilian queer theorists. (Of course there are much more scholars working with gender and sexuality through non-normative lenses, though not necessarily calling themselves queer theorists). Queer ideas are hence often regarded by LGBT activists as elitist, foreign, abstract or useless. In Latin America, the adhesion to the word 'queer' is polemical because of its foreignness and potential perpetuation of white codes and meanings. Nevertheless, appropriations have subverted the Anglophone spelling - from queer to kuir, cuir, cuier - and created new meanings (Ferreira 2016; Pelúcio 2014). Later in this forum contribution, I articulate queer ideas and tensions from artists and activists that do not necessarily consider themselves 'queer,' or that even defy queer academic productions because those reinforce a colonial and classist status quo. Nevertheless, I insist on using 'queer' because my aim is to emphasize the conversations between institutional limitations and radical ideas. 'Queer' is maybe a simpler word to condense the latter.

In this contribution, then, I keep 'queer' as a reference to dissident ideas seeking the scrambling of presumptively neutral heterosexual thought and its norms; it does not mean simply giving up any kind of identification (Miskolci 2011). Instead, queer thought is presented here as a set of intellectual efforts to decipher what makes heterosexuality seem natural and how it implies the maintenance of a status quo which ends up undermining other political possibilities regarding sex, gender, family, the public/private sphere, and violence. In this sense, Berlant and Warner (1998: 553) propose that heteronormative

$[\mathrm{C}]$ onventions conjure a mirage: a home base of prepolitical humanity from which citizens are thought to come into political discourse and to which they are expected to return in the (always imaginary) future after political conflict. Intimate life is the endlessly 
cited elsewhere of political public discourse, a promised haven that distracts citizens from the unequal conditions of their political and economic lives, consoles them for the damaged humanity of mass society, and shames them for any divergence between their lives and the intimate sphere that is alleged to be simple personhood.

Hence, an openness to queer ideas potentially enriches social movements' articulations, providing deeper reflection on how heterosexual norms are inextricable from the formation of an unequal and widely oppressive social fabric, particularly for non-cisgender people.

When recalling Stonewall from the present moment in Brazil, current political conditions must not be ignored: the fact that Stonewall's $50^{\text {th }}$ anniversary commemorations took place in the year of fascist president Jair Bolsonaro's first mandate caused a general fear of regression and led to a reinforcement (or justification) of the rhetoric of tolerance and rights. At the same time, this rhetoric was already central to agendas of previous LGBT parades. In 2015, the São Paulo Pride Parade had as its theme 'Eu nasci assim, eu cresci assim, serei sempre assim: respeitem-me': 'I was born this way, I grew up this way, I will always be this way: I demand respect' (Carvalho 2019).

Legal protection is undoubtedly important. In Brazil, we have taken some steps in the judicial sphere. The National Supreme Court has recently criminalised trans/homophobia and recognised transgender identity, and the National Council of Justice approved a resolution guaranteeing same-sex marriage rights in the entire national territory. Although the question of matrimony and criminalisation of trans/homophobia is polemical, these topics will not be further developed here but are part of a necessary dialogue within the community. Regarding transgender people, sex/gender confirmation (or reassignment) surgery is provided by the national public health care system (SUS - Sistema Unico de Saúde). However, most advances are achieved through the National Court, which reveals a political fragility due to the fact that the Brazilian parliament is conservative, and legislative changes in favour of LGBT people and anti-trans/homophobic socialisation and education are barely imaginable (Quinalha 2019).

According to Joshua Gamson (1995), there is a simultaneity between cultural sources of oppression - that permit the loosening of identity categories - and institutional sources of oppression - which require dealing with the state and rigid legal structures and identities. In Brazil, concomitantly to significant (although also fragile) legal and institutional achievements made by LGBT articulations, the country tops the world ranking of transgender people killings, with $82 \%$ of them being non-white (Benevides and Nogueira 2020).

Under these circumstances, LGBT movements in the country began to emphasize the need for transgender protagonism, and they often remember and honour trans of colour activists Marsha P. Johnson and Sylvia Rivera as pioneers of the movement and leaders of the Stonewall uprisings. Johnson and Rivera ${ }^{2}$ dedicated their lives for rights and freedom from police and civil violence for queer people and were ostracized by transphobic gay and lesbian activists - although 'transgender' was not a common term at that time. Moreover, progressive LGBT activists of today usually emphasize the need for intersectionality, which is again frequently put in identitarian terms of inclusion and 'giving space' 
to the demands of the most oppressed and their varied life backgrounds. At least, this has been a popular meaning of intersectionality, one often coopted by liberal discourses, which has been key to denote an alleged awareness of deep violence and oppression.

As Kathy Davis (2008) wrote, intersectionality has become a buzzword. I suggest that, instead of responding to social problems exclusively within an identitarian framing, LGBT activists and queer theorists could fruitfully build a discursive ground that highlights compulsory cis/heterosexuality and whiteness as webs of social structures and cultural formations constituting the very basis of a self-righteous and violent society. For instance, inspired by the writings of Monique Wittig (2006), Ochy Curiel, a decolonial lesbian feminist from the Dominican Republic, conceives compulsory heterosexuality (which is her key term, instead of Duggan's or Warner's heteronormativity) as a political regime. For Curiel, compulsory heterosexuality transcends experiences of sex and gender; it is cultural, structural, part of the white colonial project materialised through deeply sexualised white fears, projections and concepts of alterity (Curiel 2013, 2014). This conception has some similarities to Michael Warner's understanding of heteronormativity already presented here but departs from a colonial experience, with decolonial goals centered on critical studies for political action. Curiel's contributions are enriching because politicising sexuality in an imbricated manner helps to clarify power structures and to put questions of identity in a wider political scope, which is a promising direction for queering LGBT movements in Brazil.

If nowadays the achievement of rights allows LGB people to put aside their status as deviant subjects in many institutional and social life spheres due to recognition and respectability, then remembering Stonewall can be worthwhile if this memory not only encourages resistance through remembrance of the times when all LGBT people were relegated to marginality. (I intentionally say LGB because in most cases trans people's hypervisible 'deviance' means that they cannot put it aside as easily as LGB people.) If this is the dominant narrative, it may carry a linear logic of limited liberation: LGB people tend to be satisfied with inclusion and rights, withdrawing from wider possibilities of liberation as we feel comfortable within the status quo in which we live (especially if 'we' are LGB elites). Within this political horizon, we continue negotiating tolerance, which, as Wendy Brown (2006) argues, means above all a minimum line of acceptance towards different behaviour. From the 'tolerant' point of view, the other is still seen as deviant and should be included to the extent that they do not disturb heterosexual norms and modes of politicising sex.

When Richard Miskolci (2011) identifies anti-trans/homophobia as the main and wider agenda of Brazilian LGBT politics, he proposes that fighting trans/homophobia allows for both queer and identity politics. From the latter perspective, the decision of the Brazilian Supreme Court equating LGBTphobia with the crime of racism, for instance, is feasible precisely because a certain group is identified around non-cis/heterosexual identities. That is, LGBT subjects are protected from violence because they have the right to be who they are.

On the other hand, this is where queer and identitarian articulations can set a conversation, since trans/homophobia is deeply embedded in heterosexual ideology - which is 
precisely what queer paradigms aim to emphasize and undermine. Anti-trans/homophobia gives room for political mobilisations departing from the collective question of 'what we want' rather than 'what we are', as Wendy Brown (1995) once put it in a critique of purely identitarian politics. If we consider transphobia (often murderous crimes) as the most crucial problem in Brazilian sex politics, it leads us deeper into cultural questions of sex, gender and alterity beyond the need for legal protection, since death and loss cannot be reverted by judicial decisions.

In Normal Life, Dean Spade (2011) argues that legal recognition and inclusion fails the task of improving material circumstances for a dignified and secure life for trans people. Criminalisation of hate crimes does not dissuade violence: rather, it focuses on punishment. In other words, violence against transgender, transsexual and sexually dissident bodies is not only a question of discrimination, but one of deeply embedded social structures. In the section below, I offer three contexts where trans and travest $i^{3}$ experiences, ideas and positions generate tensions regarding institutional arrangements (even proLGBT ones).

\section{Scenes and questions from the margins; or, why queering is necessary I}

Linn da Quebrada, a black travesti artist, had her presentation cancelled at the João Pessoa (a small capital in Northeastern Brazil) Pride Parade 2019, which also celebrated the Stonewall uprisings and emphasized LGBT rights. Linn's lyrics are profoundly political, anti-phallocentric (consequently anti-heteronormative and anti-homonormative) and feature explicitly sexual(ised) terms and slangs from the travesti community. In a leaked cellphone audio, one of the organisers said Linn da Quebrada's work was too offensive to the general public and therefore not the best choice for a Pride Parade supported by the local City Hall. Mermaid, the official DJ of João Pessoa Pride Parade for 18 years and member of a local LGBT organisation, complained - in their own opinion of the artist's language - about Linn da Quebrada's vocabulary and suggested that the parade would be reprimanded if the artist performed. ${ }^{4}$ Here we witness the erasure (censorship) of a queer language that exposes the violence of heterosexism by an institutionalised movement concerned with the respectability of the artist's discourse.

João Pessoa Pride organisers were concerned with a public presentation expressing the ideas of 'a gay movement you could take home to Mom,' as Michael Warner (1999:42) once affirmed - maybe exaggeratedly. The thin line between transgression and tolerable speech was drawn there: Linn was announced in the Parade's musical line-up and cancelled later on because organisers were afraid of future problems with the straight public and with sponsorship. For the sake of guaranteeing next year's Pride Parade, a black travesti voice was to be shut up. In order to maintain an LGBT event created to fight trans/ homophobia and demand rights, anti-phallocentric art was censored. It seems paradoxical precisely because trans and homophobia are rooted in masculinity, phallocentrism, among other axes of power.

As a response, a group of black queer activists decided to start a crowdfunding initiative for an event called Parada Preta (Black Parade) featuring Linn da Quebrada, for 
whom the official Pride Parade cancellation was motivated by transphobia. Parada Preta made a queer black event with Linn - in opposition to a normal LGBT event - where police violence, racism and transphobia were exposed out loud.

\section{Scenes and questions from the margins; or, why queering is necessary II}

In the 1980s, travesti activists of ASTRAL (Travestis and Liberated People Association/ Associação de Travestis e Liberados) in Rio de Janeiro gathered to protest against the urban sweeps and police belligerence that denied their rights to mobility and freedom from violence. Leader Jovanna Baby demanded exemption from citizenship duties and obligations, including the registration of their names and gender, the obligation to vote in elections and to pay taxes. They destroyed their Brazilian identity documents and appealed to the international community in order to assert their status as global citizens. They were not demanding greater police protection or greater state intervention, nor the passing of hate crime laws. They insisted that the state be held accountable for the murder of travestis and claimed a global scale of recognition and agency (Amar 2013).

At that time, even criminalisation of transphobia would not seem effective, since ASTRAL travestis did not feel like citizens because they were violated by agents of the very sovereign State they lived in and should be protected by. Nowadays, police violence remains, but the Supreme Court decision to criminalise homo/transphobia in Brazil has, as Spade (2011) alerted, the effect of conceiving violence as individual discrimination while presenting the judicial system - which spills over to the State as a whole, in the eyes of the general public - as a neutral instance regarding gender norms and violence.

\section{Scenes and questions from the margins; or, why queering is necessary III}

Also in Rio de Janeiro, Casa Nem is home to black, travesti and transgender people, some of them sex workers. It was founded by activist Indianare Siqueira and is sustained by herself, other activists and residents, and public donations. Seen from a sexually normative angle, Casa Nem's residents are close to abjection or simply abject. Their life experience (poverty, family abandonment or abuse) and unintelligibility to sex and gender norms make them assailable and indefensible in terms of full citizenship. According to Judith Butler (1999: 23), deeply rooted gender norms can even determine who counts as a person or as less than a person (let alone a citizen):

[T] he "coherence" and "continuity" of "the person" are not logical or analytic features of personhood, but, rather, socially instituted and maintained norms of intelligibility. Inasmuch as "identity" is assured through the stabilizing concepts of sex, gender, and sexuality, the very notion of "the person" is called into question by the cultural emergence of those "incoherent" or "discontinuous" gendered beings who appear to be persons but who fail to conform to the gendered norms of cultural intelligibility by which persons are defined. 
"Intelligible" genders are those which in some sense institute and maintain relations of coherence and continuity among sex, gender, sexual practice, and desire.

Siqueira, who presents herself as a 'normal woman with a dick and breasts' (Abbade et al 2016: 411), carries out a political and aesthetic action that uncovers such relations of gendered coherence constituting social and legal structures and expectations. Her performance consists of showing her breasts and drawing the attention of the police with two goals: the first is to denounce the inequality of legal provisions in relation to men and women, proving that we are not all equal before the law, and the second is to eliminate the need for gender definition in identification documents. Because documents define her as male, she is taken to the police station for civil misconduct (nudity) but cannot be legally convicted. In the same body, she is not condemned for being a man, but would be condemned if she were, legally, a woman (Abbade et al 2016).

Indianare also addresses feminist transphobia as a masculine and sexually normative discourse. She is, therefore, theorising gender from her own bodily experience:

$[\mathrm{C}]$ is women, especially radical feminists, say that women have pussy and uterus and use their uterus to oppress other women. But who said that a woman is a person with an uterus and a pussy? Men said that. [....] When travestis and transsexual people say "I am a woman" and they answer "No, you are not women!" Isn't that what men told them? "You are not men, you are women", and they accepted it (Abbade et al 2016: 417, my translation).

The activist politicises her transgender feminine body as the materialisation of a binary structure determined by white cisgender men. Indianare, then, keeps on doing her performances and keeps Casa Nem alive by disproving gender norms embedded in law, institutions and certain allegedly progressive positions on a daily basis.

The experiences and political statements of Linn da Quebrada, ASTRAL and Indianare Siqueira inspire us to raise a fundamentally queer question: do identity politics suffice to attend wider demands for justice? Are identitarian - including intersectional - approaches enough to diagnose complex and violent questions which constitute the very structure of liberal (and colonised) States?

\section{Concluding remarks}

Recalling Joshua Gamson's categorisation of cultural and institutional sources of oppression, it seems that identity politics must be constructed along with a politization of structures of domination, which are cultural. In this paper I have reflected, departing from US narratives and then specifying Brazilian particularities, upon how queer positions and thinking are powerful and should be welcomed by LGBT activists who strongly rely upon identity politics, because dissident bodies need an expanded debate comprising their claims to a dignified life. 
As long as LGBT activism and the memory of Stonewall uprisings focus solely on rights and identity, instead of power, we risk forgetting how every structure giving shape to our daily lives is rooted in compulsory heterosexuality and the State regulation of gender and racial non-conforming bodies. That is why Linn da Quebrada, Jovanna Baby and Indianare's activisms bring about tensions that shake the very core of the discussion between institutional/identity politics and queer struggles.

\section{A Brazilian Stonewall: Notes on Lesbian Activism}

Amanda Álvares Ferreira

In 2019 , the $50^{\text {th }}$ anniversary of the Stonewall events was celebrated worldwide in different LGBT $^{5}$ parades. The violent confrontations between gay activists and the police that took place in June 1969 in New York became a symbol of LGBT resistance, and that now has become a commonsense reference when talking about activism and history and that marks the $28^{\text {th }}$ of June as pride day. These violent encounters were marked by a positioning by LGBT activists that became an example to be followed: in Europe, radical groups demanded not only civil rights but also a 'radical change in society, proclaiming the abolition of differences between sexual parts exercised by men and women, and also the stereotyped patterns of masculinity and femininity' (Macrae 2011: 27).

Meanwhile, in Brazil, it was only by the end of the 1970s, a few years before the crisis of AIDS, that a LGBTTI ${ }^{6}$ rights movement consolidated itself, when the military dictatorship began its slow process of opening and social movements conquered some space to act in the public sphere. (The military dictatorship also (violently) persecuted and targeted homosexuals and transsexuals, with the pretension of sanitizing society in face of an ideal subjectivity that would fit into the nuclear, monogamic, patriarchal and heterosexual family model (Green et al 2018: 10).) It was in 1978 that the group SOMOS (Grupo de Afirmação Homossexual/Group for Homosexual Affirmation) was formed, articulating the MHB (Movimento Homossexual Brasileiro/Brazilian Homosexual Movement) that worked as a trigger to the formation of several other groups around the country. Around that time, newspapers such as Lampião da Esquina (1978) and Chana com Chana (1981) started circulating talking about, respectively, the gay and lesbian political fights. After 40 years, the movement has largely evolved, and that includes the conquest of several rights for the LGBTTI population (with laws for marriage for same sex couples, and laws for trans persons' social names). However, a number of questions can still be posed, some older than others. 
At the beginning of June 2019, a few days before São Paulo's pride parade, the Brazilian Supreme Court determined that discrimination for sexual orientation and gender identity would be considered a crime: homophobia was criminalized by a parallel drawn with laws against racism. The debate opened by this decision inside the LGBTTI community, was whether this criminalization would only end up incarcerating those same vulnerable bodies that are already marginalized in Brazilian society, instead of bringing structural changes to homophobia in the country.

As Berenice Bento (2017) argues, we expect the law to transform 'social consciousness' and end intolerance, but, in fact, it is also necessary to search for other paths to confront society and create a foundation, in the social level, for the laws that would ensure our protection and survival. Thus, the question that is latent is whether criminalizing homophobia would have a truly positive impact in building equality. We search for reparation via judiciary (and add to a penal State that mostly criminalizes black lives), but that will not necessarily build up to a more equal society. There is, in Bento's terms (2015), little continuity between the terms of the law and life in itself, but the State keeps on having a protagonistic role in defining our agendas and disputes. So, the first question is whether we are searching for a 'juridical utopia' while that would only benefit a specific economic elite (Carrara, cited in Colling 2011: 10), and we would have a law that does not reflect any changes in society toward homophobia and transphobia.

An expression of this paradox is the rise in homophobic speech that accompanies the growth of extreme right movements in the country. Arguments adopted by rightists/ conservatives that criminalizing homophobia would preclude 'freedom of expression and religion' are symptomatic of how 'freedom' can be 'easily appropriated in liberal regimes for the most cynical and unemancipatory political ends' (Brown 1995: 5). While freedom works under neoliberal terms of absence of coercion to individual action, of mere conceptions of private rights, it opens space for 'freedom of expression' to become hate speech toward any form of expression of the social, of reparation and justice to minorities, or equality.

A discussion on freedom, which will not be developed in the scope of this forum contribution, reinforces the necessary question of whether we should only aim for an equality of rights in face of the State, or for demanding a radical questioning of cisgender norms and heterosexuality as a goal. So, it is important to question what are the consequences of a homonormativity that has consolidated itself over the last 50 years. As argued by Lisa Duggan (2003: 50), homonormativity is 'a politics that does not contest dominant heteronormative assumptions and institutions, but upholds and sustains them, while promising the possibility of a demobilized gay constituency and a privatized, depoliticized gay culture anchored in domesticity and consumption.

On the one hand, a reflection of this homonormative consolidation becomes obvious when we look at the cooptation of LGBTTI causes by various consumer brands at moments such as Pride month (when several of them sponsor parades around the country), which finally causes some debate on whether the LGBTTI parade lost its political focus once it became a capitalized event. On the other hand, the question remains open on 
whether we have achieved a new form of sexual morality that expands the matrix of acceptable desires but keep queering certain bodies, dislocating deviation and turning them abject for their gender identity, as in the case of continuous exclusion and marginalization of travesti identities in Brazil.

The greater acceptance and visibility of sexual and gender minorities is a result of activism reclaiming the existence of LGBTTI people and trying to resist homophobia, and it is necessary to consider how this has entailed the organization of such minorities around identity categories that we know as the L, G, B, and the unfortunately least 'included' of them all, $\mathrm{T}$; and how necessary this movement was for the existence of a possible dialogue between diverse expressions of gender and sexuality, for them to be represented. But this move also depended on the understanding that who you desire, or who you have sex with, determines, at least to some extent, who you are (Rao 2010). As Warner (1999: 9) puts it, 'variant desires are legitimate only if they can be shown to be immutable, natural, and innate.' As a result, LGBT identities managed to be considered legitimate in the terms of modernity, and to become mainstream as they are granted legal rights and consolidate a consumer opportunity (Kapoor 2015).

Perhaps homonormativity would be an unexpected unfolding after 50 years since the Stonewall riots, as some aspects of being LGBT have become almost 'normal.' As such, the celebration of Stonewall should make us look back at this event and its revolutionary demands, questioning how much our demands are, or have become, influenced by heteronormativity, in a move that is sometimes called assimilationist (Colling 2011), as well as recognizing the fact that this homonormativity, besides expressing class privilege, is inherently connected to a matter of racism. Therefore, for this forum, we will look specifically at the connection of Stonewall and Brazilian LGBTTI activism, and how this activism responds to structural violences. I will focus on the impact of lesbian activism and how thinking lesbianism could help us approach the questions posed above, such as the judicialization, homonormativity and capitalization of LGBTTI causes.

\section{Ferro's Bar, a 'Brazilian Stonewall'}

Marisa Fernandes (2018) describes a number of important events that took place at the beginning of the 1980s and that mark the pillars of lesbian (and LGBTTI) activism up until today. From 1980 on, the group named GALF (Grupo de Ação Lésbica Feminista/Group for Lesbian and Feminist Action) 'acted strongly against the wave of arbitrary prisons, tortures and extortions' (Fernandes 2018: 98) of over 1500 people that were indiscriminately arrested during the last years of the dictatorship: homosexuals, travestis, prostitutes or unemployed people. Because of that, an open letter and a protest were organized on 13 June 1980 by homosexual organized groups, the unified black movement and feminist collectives in São Paulo. The iteration 'PELO PRAZER LÉSBICO e CONTRA A VIOLÊNCIA POLICIAL' ('FOR LESBIAN PLEASURE and AGAINST POLICE VIOLENCE'), known until today as one of the first public lesbian claims in Brazil, called attention at this context. 
Another event that achieved visibility took place in 23 July 1983, when a group of lesbians (from GALF) were selling the newspaper ChanacomChana (Oliveira 2017), and because of this were not allowed to enter Ferro's Bar. A political act was then planned for 19 August of the same year, articulating lesbians, gays, feminist activists and the press. This act became a historical landmark and marks the celebration of the 19 of August as lesbian pride day. Both of these events at Ferro's Bar are differently cited as a Brazilian Stonewall (see Fernandes 2018; Lopes de Camargos 2018).

These events, still, seem to have a small repercussion considering how widespread is the recognition of the events at New York's Stonewall Inn in Brazil: in June 2019, some shy references to Ferro's Bar appeared in the media (see, for example, BBC News Brasil 2019; Martin 2019), mostly associated with a description of what Stonewall was. What seems predominant is that there is a strong relation between North American archetypes and the way we organize our memory and culture in relation to what concerns a LGBTTI Brazilian history, in our identitarian organization or in the reproduction of LGBT parades (Trindade 2018), and most certainly in the construction of a homonormativity.

But it also seems that our 'founding' events are marked not by a mere gay 'we', or even a mere LGBTTI, but by a diversity of identifications that exceeds the acronyms. This movement makes queer interesting as a lens for the Brazilian context: as a lens that considers an alliance which departs from difference in order to think critically of how we, as LGBTTI, engage with the State as the institution that acknowledges, or not, our existence, and that provides our basic rights - 'to pleasure and against police violence.'

\section{'Sapatão é Resistência'? a queer iteration?}

The early and the contemporary lesbian movement in Brazil epitomize a number of struggles and questions that have marked LGBTTI, and not only lesbian, academic and activist debates over the last 40 years. It explicitly targets, in its speech, what would be the vectors of gender and sexuality oppression.

There are important considerations, such as Adrienne Rich's ${ }^{8}$ (1980), of how lesbian experience has been excluded from feminist academic thinking and writing, or of how lesbians have been marginalized in contexts of activism in detriment of gay activists (Fernandes 2018: 93; Santos et al 2017). There is, up until today, a strong rhetoric that claims that lesbians have been erased from several different contexts: their experiences of sexuality are deemed invisible not only outside, but also inside LGBTTI and leftist communitarian spaces, and they are considered erased because of the joint exercise of patriarchy, capitalism and racism (Oliveira 2017). According to Luana Farias Oliveira (2017), the lesbian movement is at the intertwinement of the feminist and homosexual movement, forming a radical critique of sexual norms. However, lesbians have recognized both machismo and misogyny in the homosexual movement and heterocentrism in the feminist movement.

Lesbian activism and thinking are inherently marked by a connection between feminism and lesbianism that is a useful and fruitful 'source of power and knowledge available 
to women' (Rich 1980: 633). To put it differently, affirming a sapatonice (dykeness), being sapatão (a dyke), includes the demands of a multiplicity of identifications, and it provides a fertile field that can also embrace trans masculinities and trans femininities. Affirming a Brazilian lesbianidade (lesbianism) exposes an identity to be affirmed for the political terms of the Nation-State, but that, in fact, exceeds the essentialism of a metaphysics of substance, since it is radically queer (Butler 2016: 56).

Affirming that being a lesbian implies resisting provides the possibility of multiple existences that can exceed a strategic essentialism: it provokes a displacement of the understanding of the subject, as being a sapatão implies different expressions and identifications as butch, lesbian, dyke, etc. It allows us to think of how these iterations would be the affirmation of the building of a community on the basis of difference, in a queer affirmation of multiple lesbian existences. After all, queer, in Judith Butler's (2011: 228) terms, can only be:

[A] site of collective contestation, the point of departure for a set of historical reflections and futural imaginings, it will have to remain that which is, in the present, never fully owned, but always and only redeployed, twisted, queered from a prior usage and in the direction of urgent and expanding political purposes.

In other words, queer can work as a key to exceed those identity categories that still seem so insistent as the only possibility of existence. Exercising theory and activism in a disidentified way (Muñoz 1999), which could be considered a queer way, would be a form of conceptualizing processes of constitution of gendered subjects departing from trans, travestis, sapatonas, of thinking from zones of abjection, instead of researching those who apparently are situated in, or even, as the norm. Not only that, it is a way of allowing lesbian existence to be inclusive of identifications that exceed the limited understanding of being a lesbian as being a 'cis' woman who desires another 'cis' woman.

It is important to remember that there has been a tension between some activists and those who were labelled as queer since queer theory problematizations have appeared in Brazil via universities, in the 1990s, but, since then, important appropriations have been made turning queer theory into an asset to be used in order to think a critical dialogue both with the State and with capitalist pressures that strengthen a regime of normality today (Lugarinho 2001; Miskolci 2011).

Iterations such as 'ser sapatão é resistência,' or its variations 'sapatão é (re)existência' ('dyke is (re)existence'), 'sapatão é revolução' ('dyke is revolution'), and 'ser sapatão é um ato político' ('being dyke is a political act'), have become frequently articulated in diverse spaces of lesbian social interaction, in artistic productions, in cyber activisms, in fanzines, in LGBT parades (and events like the Caminhada de Mulheres Lésbicas e Bisexuais de São Paulo/the São Paulo Lesbian and Bisexual Women's Walk), among others. This consideration that being a lesbian means resisting something might target different terms such as 'patriarchy', 'compulsory heterosexuality', 'machismo,' 'misogyny', as well as the 'State as promoter of violence.' There is, then, a search for contesting the invisibility of lesbianism, 
and, therefore, for claiming, performatively, the status of an intelligible subject, of the possibility of existing in itself. Namely, through the affirmation of lesbianidade and through visibility there is a demand that the life of these people can be lived (Butler 2015).

Even though lesbian activism reiterates, for example, the right to pleasure as a demand for recognition of their existence, it has done such reiteration with a potential for exceeding the model I quoted above, the one which prescribes that one's subjectivity is determined by one's desires, that would be the only path to making LGBTTI bodies somehow intelligible for contemporary politics. Not only that, the affirmation of the word sapatão, or even the word lésbica (lesbian) itself, is also a resignification of a word that once had a bad connotation into a word of affirmation and demand for visibility, emptying it of its violent content.

By way of conclusion, the claim that being a lesbian is a political act shows how developing lesbian activism locates politics at the level of bodily experience and therefore expresses that the questioning of exercises of power over one's subjectivity is essential for a radical questioning of contemporary institutions that express normalized conceptions of gender, race and class. Affirming a lesbianidade is in line with Audre Lorde's (2020: 54) proposal that breaking silence is a way of attenuating differences (or opening a space for creating alliances) and provoking action, resignifying language in order to cause transformation.

With the inheritance of a struggle not only for gender equality but for democratization, lesbian existence (Rich 1980) nowadays opens a space for thinking present institutions of power and which bodies are made invisible, made abject in Brazilian society, whether LGBTTI or not (Cohen 1997). What is at stake, then, is how this LGBT-eternallychanging community is willing to look at how our subjectivities are built inside the norm and how we can subvert that in our relations between subjects and with institutions.

In other words, lesbian communitarian spaces and activism can help us question how our identities are historically built and founded, in an exercise that can help recall the revolutionary demands posed at events such as Stonewall's and Ferro's bar, and memorialized over the last year, in order to think the questions asked in the first section of this text, putting into scrutiny what has become normal through homonormativity, and what are the consequences of it to our lives. After all, visibility towards LGBTTI causes has different effects on different bodies, and being aware of the intersectionality that has historically marked different lives is the potentiality in present lesbian thinking. As such, it seems only important that LGBTTI academic thinking or activism take into consideration that the language of judicialization for building equality, as I mentioned above, can have unequal consequences for those who are not an elite, or who are not normalized as respectable in a new regime of normal that might include some homosexual (and white) identities. 


\section{Notes}

1 [Note by Belmont] Brazilian left-wing government led by João Goulart suffered a military coup in 1964 followed by dictatorial regimes. Redemocratisation gradually began by the end of the 1970s.

2 [Note by Belmont] Raul A. Reyes recalls: 'With her friend and fellow activist Marsha P. Johnson, Rivera founded STAR (Street Transvestite Action Revolutionaries) and opened a shelter for homeless transgender youth. She was also an early member of groups like the Gay Activists Alliance and the Gay Liberation Front, which were the forerunners of today's LGBT advocacy organizations' (Reyes 2015).

3 [Note by Belmont] According to Ferreira (2018), travestis pursue a transsexual identity but do not necessarily (want to) go through gender reassignment surgeries; there is a wide range of bodily representations among them, and to define their gender is to risk falling into serious generalisations.

4 [Note by Belmont] This was recounted in information posted at Linn's Instagram account: https://www. instagram.com/p/B0rCpy_FY_5/.

5 [Note by Ferreira] LGBT stands for Lesbian, Gay, Bisexual, Transgender. I adopt the acronym at this point in the text because of its common use and recognition.

6 [Note by Ferreira] LGBTTI stands for Lesbian, Gay, Bisexual, Transexual, Travesti, Intersexual. The choice of this acronym throughout the text follows Berenice Bento (2017) in affirming the specific gender identity of travestis, which is endogenous to the Latin American context. I do not adopt the Q in the acronym for I consider that queer itself is the negation of the acronym, of identities at all (Butler 2011).

7 [Note by Ferreira] Dyke is Resistance.

8 [Note by Ferreira] 'Any theory or cultural/political creation that treats lesbian existence as a marginal or less "natural" phenomenon, as mere "sexual preference," or as the mirror image of either heterosexual or male homosexual relations, is profoundly weakened thereby, whatever its other contributions. Feminist theory can no longer afford merely to voice a toleration of "lesbianism" as an "alternative life-style," or make token allusion to lesbians' (Rich 1980: 632).

\section{References}

Abbade, A M, M Pimentel, D Mattos and G Altmayer. 2016. “Que a liberdade ensine pessoas": Entrevista com Indianara Siqueira.' Concinnitas 28 (1): 411-426.

Amar, P. 2013. The Security Archipelago - Human-Security States, Sexual Politics and the End of Neoliberalism. Durham and London: Duke University Press.

BBC News Brasil [online]. 2019. '50 anos de Stonewall: saiba o que foi a revolta que deu origem ao dia do orgulho LGBT. 19 June. At https://www.bbc.com/portuguese/geral-48432563 [Accessed on 26 August 2020].

Benevides, B G and S N B Nogueira. 2020. Dossiê dos assassinatos e da violência contra travestis e transexuais em 2019. São Paulo: Expressão Popular, ANTRA, IBTE.

. 2015. 'Apresentação.' In L Colling (ed), Que os Outros Sejam o Normal: tensões entre movimento LGBT e ativismo queer. Salvador: EDUFBA, n.p.

Bento, B. 2017. Transviad@s: gênero, sexualidade e direitos humanos. Salvador: EDUFBA.

Bronski, M. 2019. 'Sexual Liberation Versus Identity Politics.' In R Schneider Jr (ed), In Search of Stonewall: The Riots at 50, The Gay \& Lesbian Review at 25. Best Essays, 1994-2018. Boston: G\&LR Books, n.p.

Brown, W. 1995. States of Injury: Power and Freedom in Late Modernity. Princeton: Princeton University Press. 
2006. Regulating Aversion: Tolerance in the Age of Identity and Empire. Princeton: Princeton University Press.

Butler, J. 1999. Gender Trouble: Feminism and the Subversion of Identity. New York and London: Routledge.

2011. Bodies that Matter: On the discursive limits of sex. New York: Routledge.

2016. Problemas de Gênero: Feminismo e subversão da identidade. Rio de Janeiro: Civilização

Brasileira.

Camargos, M L de. 2018. 'O Surgimento das Paradas LGBT no Brasil.' In J Green, R Quinalha, M Caetano and M Fernandes (eds), História do Movimento LGBT no Brasil. São Paulo: Alameda, pp. 421-434.

Carvalho, K. 2019. 'Parada LGBTI+: Relembre a história e temas anteriores'. Observatorio G [online]. 8 June. At https://observatoriog.bol.uol.com.br/parada-lgbt/parada-lgbti-relembre-a-historia-e-temas-anteriores [Accessed on 1 June 2020].

Cohen, C J. 1997. 'Punks, Bulldaggers, and Welfare Queens: The radical potential of queer politics?' GLQ 3: 437-465.

Colling, L. 2011. Stonewall 40+ o que no Brasil? Salvador: EDUFBA.

2015. Que os outros sejam o normal: tensões entre movimento LGBT e ativismo queer. Salvador: EDUFBA.

Curiel, O. 2013. La Nación Heterosexual: análisis del discurso jurídico y el régimen heterosexual desde la antropología de la dominacíon. Bogotá: Ed. Brecha Lésbica y en la frontera.

2014. 'Género, raza, sexualidad: debates contemporáneos.' Colombia: Universidad del Rosario [online]. At https://www.urosario.edu.co/Subsitio/Catedra-de-Estudios-Afrocolombianos/ Documentos/13-Ochy-Curiel---Genero-raza-y-sexualidad-Debates-.pdf [Accessed on 30 May 2020].

Davis, K. 2008. 'Intersectionality as buzzword: A sociology of science perspective on what makes a feminist theory successful.' Feminist Theory 9 (1): 67-85.

Duggan, L. 2003. The Twilight of Equality? Neoliberalism, Cultural Politics and the Attack on Democracy. Boston: Beacon Press.

Facchini, R and J A Simões. 2009. Na trilha do arco-íris: Do movimento sexual ao LGBT. São Paulo: Fundação Perseu Ábramo.

Fernandes, M. 2018. 'Ações Lésbicas.' In J Green, R Quinalha, M Caetano and M Fernandes (eds), História do Movimento LGBT no Brasil. São Paulo: Alameda, pp. 91-120

Ferreira, A A. 2018. 'Queering the Debate: Analysing Prostitutioin Through Dissident Sexualities in Brazil.' Contexto Internacional 40 (3): 525-547.

Ferreira, G B. 2016. “'Arte Queer” no Brasil? Relações raciais e não-binarismos de gênero e sexualidades em expressões artísticas em contextos sociais brasileiros.' Urdimento 2 (27): 206-227.

Foucault, M. 1988. História da Sexualidade I: A vontade de Saber. Rio de Janeiro: Edições Graal.

Gamson, J. 1995. 'Must Identity Movements Self-destruct? A Queer Dilemma.' Social Problems 42 (3): 390-407.

Green, J, R Quinalha, M Caetano and M Fernandes (eds). 2018. História do Movimento LGBT no Brasil. São Paulo: Alameda. 
Kapoor, I. 2015. ‘The Queer Third World.' Third World Quarterly 36 (9): 1611-1628.

Long, T L. 2005. AIDS and American Apocalypticism - The Cultural Semiotics of and Epidemic. New York: State University of New York Press.

Lorde, A. 2020. Irmã Outsider: Ensaios e Conferências. Belo Horizonte: Autêntica.

Lugarinho, M C. 2001. 'Como Traduzir a Teoria Queer para a Língua Portuguesa.' Revista Gênero $1(2): 36-46$.

Macrae, E. 2011. 'Os Respeitáveis Militantes e as Bichas Loucas.' In Leandro Colling (ed), Stonewall 40+ o que no Brasil? Salvador: EDUFBA, pp. 21-35.

Martin, F. 2019. “'Stonewall brasileiro” aconteceu em São Paulo nos anos 1980, durante reabertura política do país.' O Globo [online], 28 June. At https://oglobo.globo.com/sociedade/stonewall-brasileiro-aconteceu-em-sao-paulo-nos-anos-1980-durante-reabertura-politica-do-pais-1-23769930 [Accessed on 26 August 2020].

Miskolci, R. 2015. 'Não somos, Queremos - Reflexões Queer sobre a Política Sexual Brasileira Contemporânea.' In L Colling (ed), Stonewall 40+ o que no Brasil? Salvador: EDUFBA.

. 2011. 'Mesa 4 - Novas perspectivas e desafios políticos atuais.' In L Colling (ed), Stonewall 40+o que no Brasil. Salvador: EDUFBA, pp. 247-282.

Muñoz, J E. 1999. Disidentifications: Queer of Color and the Performance of Politics. Minneapolis: University of Minnesota Press.

Oliveira, L F. 2017. 'Quem tem medo de sapatão? Resistência lésbica à Ditadura Civil-Militar (19641985).' Periódicus 7 (1): 6-19.

ParadaSP [online]. 2019. 'Justificativa/Manifesto 23a Parada do Orgulho LGBT de SP (23/06/2019) Tema: 50 anos de Stonewall. Nossas Conquistas, Nosso Orgulho de Ser LGBT+.' 22 March. At http:// paradasp.org.br/50-anos-de-stonewall-leia-a-justificativa-manifesto-sobre-o-tema-da-parada-doorgulho-lgbt-de-2019/ [Accessed on 25 May 2020].

Pelúcio, L. 2014. 'Traduções e torções ou o que se quer dizer quando dizemos queer no Brasil?' Periódicus 1 (1): 1-24.

Puar, J. 2007. Terrorist Assemblages: Homonationalism in Queer Times. Durham: Duke University Press.

Quinalha, R. 2019. 'Os direitos LGBT sob o governo Bolsonaro'. Le Monde Diplomatique Brasil 12 (143): 4-5.

Rao, R. 2010. Third World Protest: Between Home and the World. New York: Oxford University Press.

Reyes, R. 2015. A Forgotten Latina Trailblazer: LGBT Activist Sylvia Rivera. NBC News [online], 9 June. At https://www.nbcnews.com/news/latino/forgotten-latina-trailblazer-lgbt-activist-sylvia-rivera-n438586 [Accessed on 20 July 2020]

Rich, A. 1980 'Compulsory Heterosexuality and Lesbian Existence.' Signs 5 (4): 631-660.

Santos, A C C, S B Souza and T Faria. 2017. 'Sapatão é revolução! Existências e resistências das lesbianidades nas encruzilhadas subalternas.' Periódicus 7 (1): 1-5.

Schneider Jr, R. 2019. 'Preface: In Search of Stonewall.' In R Schneider Jr (ed), In Search of Stonewall: The Riots at 50, The Gay \& Lesbian Review at 25. Best Essays, 1994-2018. Boston: G\&LR Books, n. p. Sears, A. 2005. 'Queer Anti-Capitalism: What's Left of Lesbian and Gay Liberation?' Science \& Society 69 (1): 92-112. 
Spade, D. 2011. Normal Life. Administrative Violence, Critical Trans Politics, and the Limits of Law. New York: South End Press.

Warner, M. 1999. The Trouble with Normal: Sex, Politics, and the Ethics of Queer Life. Cambridge: Harvard University Press.

Wittig, M. 2006. El pensamiento heterosexual y otros ensayos. Barcelona: Egales

\section{About the authors}

Flávia Belmont is a Ph.D. candidate in International Relations at the Pontifical Catholic University of Rio de Janeiro (PUC-Rio), and holds a master's degree in International Relations by the same institution. Her master's research focused on heteronormativity, international LGBT identity politics and redistributive justice. She is mostly interested in the imbrications between political economy, nation and identity, international theory, and feminist and queer theory. Her current academic research centres on queer and decolonial critiques of the nation-state by analysing family arrangements and forms of identification and disidentification with the Western traditional family ideal as constitutive of modernity but which has changed depending on political contexts and rhetoric.

Amanda Álvares Ferreira is a Ph.D. candidate in International Relations at the Pontifical Catholic University of Rio de Janeiro (PUC-Rio), and holds a master's degree in International Relations by the same institution. Her master's degree research focused on Latin American feminist and queer theories as well as feminist thinking on prostitution and sex trafficking. Her current research is focused on theories of sovereignty and resistance within and without the discipline of International Relations, with a specific focus on theories and practices of gender and sexuality that relate to such themes. Other research interests are contemporary feminist and queer theory, studies of gender and sexuality, political theory, and theory of International Relations. 


\title{
Perspectivas do Sul Global sobre Stonewall após 50 anos, Parte II- Stonewalls Brasileiros: Política Radical e Ativismo Lésbico
}

\begin{abstract}
Resumo: Os distúrbios contra uma batida policial em Nova York no bar Stonewall Inn em junho de 1969 são frequentemente identificados como tendo desencadeado o movimento pelos direitos LGBT e a comemoração dos distúrbios um ano depois, em junho de 1970, inaugurou uma série de eventos do Orgulho LGBT que continuam até hoje em todo o mundo. Neste fórum de duas partes, refletimos sobre os efeitos contraditórios do legado internacional de Stonewall. Nesta segunda parte do Fórum, Ferreira e Belmont investigam as formas pelas quais 'Stonewall' foi apropriado especificamente no Brasil, tanto durante a ditadura civil-militar quanto no atual momento político conturbado. Belmont localiza as incompatibilidades atuais entre as lutas LGBT e queer no Brasil ao justapor visões mais convencionais da política LGBT com as margens que elas criam, especialmente a marginalização das travestis. Belmont expõe como o discurso e as práticas LGBT dominantes reforçam a violência contínua sobre corpos dissidentes e propõe que consideremos as experiências e argumentos das travestis como contribuições necessárias para uma política mais radical (queer). Na contribuição final, Ferreira recapitula as demandas políticas dos eventos de Stonewall de Nova York e os compara às reivindicações revolucionárias do que foi chamado de 'Stonewall brasileiro.' Considerando o protagonismo dos movimentos lésbicos em eventos como esse no Brasil, sua contribuição analisa, a partir de uma perspectiva queer, o abraço de uma multiplicidade de identificações no ativismo lésbico contemporâneo. Ela argumenta que esse movimento cria potencialidades para responder a violências estruturais, ao mesmo tempo em que aborda questões como a judicialização e comercialização de causas LGBTTI e homonormatividade.
\end{abstract}

Palavras-chave: Stonewall; ativismo lésbico; homonormatividade; política queer brasileira; conservadorismo LGBT; agência travesti.

Received on 13 June 2020, and approved for publication on 17 August 2020.

\section{(c) BY-NC} https://creativecommons.org/licenses/by-nc/4.0/ 